\title{
Edible flowers - antioxidant activity and impact on cell viability
}

Research Article

Zdenka Kucekova1,2, Jiri Mlcek ${ }^{3, *}$, Petr Humpolicek¹,2, Otakar Rop ${ }^{4}$

'Centre of Polymer Systems, University Institute,

Tomas Bata University in Zlin, 76001 Zlin, Czech Republic

${ }^{2}$ Polymer Centre, Faculty of Technology,

Tomas Bata University at Zlin, 762 72, Zlin, Czech Republic

${ }^{3}$ Department of Food Technology, Faculty of Technology,

Tomas Bata University in Zlin, 76272 Zlin, Czech Republic

${ }^{4}$ Department of Gastronomy, College of Business

and Hotel Management, 62500 Brno, Czech Republic

Received 06 February 2013; Accepted 20 May 2013

Abstract: The phenolic compound composition, antioxidant activity and impact on cell viability of edible flower extracts of Allium schoenoprasum; Bellis perennis; Cichorium intybus; Rumex acetosa; Salvia pratensis; Sambucus nigra; Taraxacum officinale; Tragopogon pratensis; Trifolium repens and Viola arvensis was examined for the first time. Total phenolic content of the flowers of these plants fell between 11.72 and $42.74 \mathrm{mg}$ of tannin equivalents $/ \mathrm{kg}$ of dry matter. Antioxidant activity ranged from 35.56 to $71.62 \mathrm{~g}$ of ascorbic acid equivalents/kg of dry matter. Using the Human Hepatocellular Carcinoma cell-line (HepG2) and the Human Immortalized Non-tumorigenic Keratinocyte cell line (HaCaT), we assessed cell viability following a 3 day incubation period in media containing 25,50,75 and $100 \mu \mathrm{g} / \mathrm{ml}$ of total phenolic compounds using a colorimetric MTT assay. These three properties could make the herbs useful in treatment of various diseases like cancer. The tested extracts had significant effects on cell viability, but the effects were dependent not only on the phenolic compound concentration and the edible flowers species, but also on the phenolic compound and antioxidant profiles. In addition, responses differed between cell lines.

Keywords: Antioxidants • Polyphenols • Herbs • Cancer cells

(C) Versita Sp. z 0.0 .

\section{Introduction}

The significance of edible flowers is often evaluated from the aspect of their potential health effects, and mainly focuses on color, odor and flavor effects compared to health benefits such as antioxidant activity, free radical scavenging, and inhibition of cancers [1]. However, while the effect of individual phenolic compounds from many other plant parts has been the subject of intense scrutiny - particularly those found in wine-grape seeds and skins [2-5], tea and coffee [6-8], or fruit and vegetables - the effect of edible flowers on human health remains speculative. This question is challenging to address, as phenolic compound composition tends to vary between plant species, but also between plant parts [9].
The anticancer or preventive activity of phenolic compounds is a result of specific actions these compounds take. In previous studies, these compounds have been demonstrated to exhibited antioxidant activity [10], the trapping of ultimate carcinogens or the induction of cell apoptosis [11], the inhibition of cell proliferation-related activities [12], the cell cycle arrest [13], the nuclear oncogene expression [14], the inhibition of DNA synthesis [15], and the modulation of signal-transduction pathways by the altered expression of key enzymes such as cyclooxygenases and protein kinases [4]. These effects can be result in altered cell viability through compatibility or cytotoxicity pathways, and thus can be assessed using cell viability assays, such as the BrdU assay [16], clonogenic assay [17], 
propidium iodide staining [18], trypan blue exclusion [19] or MTT assay [20]. This widely used method is based and the colorimetric reduction of tetrazolium salt to purple formazan in viable cells, originally described by Mosmann [21].

The aim of this study was to characterize the phenolic compound and antioxidant composition in the flowers of Allium schoenoprasum, Bellis perennis, Cichorium intybus, Rumex acetosa, Salvia pratensis, Sambucus nigra, Taraxacum officinale, Tragopogon pratensis, Trifolium repens and Viola arvensis. In addition, the relationship between extract composition and concentration and the effects on human cell viability was examined for these edible flowers.

\section{Experimental Procedures}

\subsection{Plant material and extraction conditions}

The edible flowers of Sambucus nigra L. (European Elderberry, Caprifoliaceae); Allium schoenoprasum L. (Wild Chive, Liliaceae), Rumex acetosa L. (Garden Sorrel, Polygonaceae), Trifolium repens L. (Ag Yoncha, Fabaceae), Salvia pratensis L. (Introduced Sage, Lamiaceae); Viola arvensis Murray (Field Violet, Violaceae) and from the Asteraceae family: Bellis perennis L. (European Daisy); Taraxacum officinale F.H. Wigg (Common Dandelion); Tragopogon pratensis L. (Meadow Salsify) and Cichorium intybus L. (Blue Sailors) were gathered in the White Carpathian Mountains in the Zlin Region, Czech Republic during 2012.

Immediately after culling, flowers were frozen and stored at $-40^{\circ} \mathrm{C}$. The extraction was performed according to Hakimuddin et al., with modifications as provided below [22]. The frozen edible flowers were homogenized in $90 \%$ methanol $(2 \mathrm{ml} / \mathrm{g})$ and subsequently extracted at $4^{\circ} \mathrm{C}$ for 30 minutes. After extraction, centrifugation at $1990 \mathrm{rpm}$ for 10 minutes was employed to separate the supernatant and the sediment was subjected to new extraction. This process was repeated three times. The supernatants containing phenolic compounds were dried using a Laborota4011 Digital (Heidolph, Germany), and stored at $-20^{\circ} \mathrm{C}$.

\subsection{Photometric quantification of total phenolics}

The quantification of total frozen edible flower phenolic content was determined using the Folin-Ciocalteu Assay. Briefly, $1 \mathrm{ml}$ of extract was added to a $25 \mathrm{ml}$ volumetric flask, containing $20 \mathrm{ml}$ of deionized water. One milliliter of Folin-Ciocalteu's phenol reagent, (Sigma-Aldrich, USA), was added to the mixture and shaken. After three minutes, $5 \mathrm{ml}$ of $20 \% \mathrm{Na}_{2} \mathrm{CO}_{3}$ was added to the mixture. The solution was mixed and the deionized water was added, to an overall volume of $50 \mathrm{ml}$. After incubation for 30 minutes at room temperature, the absorbance at $700 \mathrm{~nm}$ was determined using a UV-Mini 1240 spectrophotometer (Shimadzu, Japan) against a prepared tannin standard solution $(0.5 \mathrm{mg} / \mathrm{ml})$. The phenolic content is expressed as $\mathrm{mg}$ of tannin equivalents $/ \mathrm{kg}$ of dry matter. All samples were analyzed in duplicates.

\subsection{Individual phenolic compounds}

Determinations of individual phenolic compounds were carried out using the Dionex UltiMate 3000 High-performance Liquid Chromatography system (Sunnyvale, California, USA). For separation and extraction of phenolic compounds, a Supelcosil LC-18-DB column $(25 \mathrm{~cm} \times 4.6 \mathrm{~mm}$ I.D. S-5 $\mu \mathrm{m})$ and the extraction method described by Lee and colleagues respectively were used [23]. Mean values from measurements in triplicate are presented. The content of individual phenolic compounds in the flowers of chosen herbs is expressed as $\mu \mathrm{g} / \mathrm{g}$ of dry matter.

\subsection{Antioxidant activity}

The DPPH (2,2-diphenyl-1-picrylhydrazyl) assay was done according to previously described methods [24,25] with some modifications. Stock solutions were prepared by dissolving DPPH (24 mg) in methanol $(100 \mathrm{ml})$, and then stored at $-20^{\circ} \mathrm{C}$ until needed. Working solutions was obtained by mixing the stock solution $(10 \mathrm{ml})$ with methanol $(45 \mathrm{ml})$ to obtain an absorbance of $1.1 \pm 0.02$ units at $515 \mathrm{~nm}$ using a LIBRA S6 Spectrophotometer. Flower extracts $(150 \mu \mathrm{l})$ were allowed to react with the DPPH solution $(2,850 \mu \mathrm{l})$ for 1 hour in the dark. Following this, absorbance was measured again at $515 \mathrm{~nm}$. Antioxidant activity was calculated as a decrease in the absorbance value using the formula: $(\%)=(A 0-A 1 / A 0) \times 100 \%$, where $A 0$ is the absorbance of the control (without the sample), and $A 1$ is the absorbance of the mixture containing the sample. The absorbance results were converted using a standard calibration curve and expressed in ascorbic acid equivalents (AAE) [26]. This protocol was repeated three times for each flower extract.

\subsection{Cell culture}

Prior to in vitro testing, samples were disinfected by exposure to an UV-radiation source (258 $\mathrm{nm})$, emitted from a low-pressure Hg lamp (UV-C Long Life 30W/G30TB, Phillips, Holland). Cell viability was assessed on two different cell-lines. In the pilot study, the Human immortalized Non-tumorogenic Keratinocyte cell-line (HaCaT) [27], supplied by Cell Lines Service (Catalog No. 300493, Germany), was cultured in 
Dulbecco's Modified Eagle Medium, a high glucose medium, with $10 \%$ fetal bovine serum and Penicillin/ Streptomycin, $100 \mathrm{~g} / \mathrm{ml}$ (PAA Laboratories $\mathrm{GmbH}$, Austria). A second, extended assessment was performed on a Human Hepatocellular Carcinoma (HepG2) cell-line from the American Type Culture Collection, HB-8065, USA. HepG2 cells were cultured in ATCC-formulated Eagle's Minimum Essential Medium, with an added $10 \%$ fetal bovine serum, $2 \mathrm{mM}$ l-glutamine and $50 \mathrm{~g} / \mathrm{ml}$ gentamycin (PAA Laboratories $\mathrm{GmbH}$, Austria) [28].

\subsection{Cell viability}

Extracts were diluted in the culture medium to obtain phenolic compound dilutions $(100,75,50$ and $25 \mu \mathrm{g}$ of phenolic compounds/ml of medium). All dilutions were used immediately. The cells were seeded at a concentration of $1 \times 10^{5}$ cells $/ \mathrm{ml}$ and pre-cultivated for 24 (HaCaT) or $48 \mathrm{~h}$ (HepG2) in 96 replica microtitration plates. The culture medium was subsequently replaced by dilutions. Culture medium without phenolic compounds was used as a control experiment. To assess cell viability, the MTT Assay (Invitrogen Corporation, USA) was performed after either a threeday (HaCaT) or seven-day (HepG2) cultivation under experimental conditions. Absorbance was measured at $540 \mathrm{~nm}$ by a Infinite M200PRO Multimode Reader (Tecan, Switzerland). Cell proliferation, expressed as MTT absorbance relative to control was the measured endpoint. Each experimental condition was replicated four times. Cell morphology was assessed after cultivation, before MTT assay, [28] via an inverted Olympus Phase Contrast microscope (Olympus, IX81). Differences between observed absorbance were detected by t-test (Statistica, StatSoft, Inc., USA).

\section{Results and Discussion}

Acharacterization of phenolic compounds of each species examined is presented in Table 1. Despite numerous studies reporting content of phenolic compounds in plants, the present work is the most comprehensive description of phenolic compounds in edible flowers. Certainly, to date, phenolic content in edible flowers is difficult to find, and for the most part, is related to antioxidant activity. For example, Brighente et al. [29] described the antioxidant activity of extracts and the fractions of six vegetal species of Baccharis (Asteraceae). However, in that work, quercetin was detected in species of the Asteraceae family, while here it was not (see Table 1). In contrast, gallic acid was detected in all species of the Asteraceae family both in that work and here. Consequently, we believe our technique to be highly sensitive.
Phenolic profiles differed greatly between the flowers we examined. For example, C. intybus mainly contained caffeic acid $(11,577.02 \mu \mathrm{g} / \mathrm{g})$, while gallic acid, ferulic acid, resveratrol and sinapic acid were present in small amounts, while coumaric acid, rutin, vanillic acid, catechin, quercetin and cinnamic acid were not present at all. Interestingly, Spina et al. [30] detected both catechin and quercetin in $C$. intybus but in the roots and leaves. The profile for $B$. perennis was quite different, as these flowers comprised mostly of vanillic acid $(2267.10 \mu \mathrm{g} / \mathrm{g})$, although gallic acid, ferulic acid, rutin, resveratrol and cinnamic acid were detected as well. In $S$. nigra, we detected only 4 compounds. S. nigra consisted mainly of caffeic acid $(913.19 \mu \mathrm{g} / \mathrm{g})$, with lesser amounts of vanilic acid $(299.38 \mu \mathrm{g} / \mathrm{g})$, gallic acid $(176.61 \mu \mathrm{g} / \mathrm{g})$, and cinnamic acid $(7.98 \mu \mathrm{g} / \mathrm{g})$. Curiously, these results contrast to that of Rieger et al. [31]. In their work, the caffeic acid was not detected in S. nigra; instead, they found rutin in high amounts, which we did not detect. In $R$. acetosa, we detected high amounts of sinapic acid $(5,708.48 \mu \mathrm{g} / \mathrm{g})$, and lesser amounts of resveratrol, vanillic acid and catechin. Although phenolic composition of $R$. acetosa has been described before in the work of Tolra et al. [32] and Stoggl et al. [33], the current study is the first to describe that of flowers. A similar situation exists with $T$. repens, as previous studies examined leaves and roots under different environmental conditions [34]. This study is the first to provide information on phenolic compounds in $V$. arvensis and $A$. schoenprasum. A high amount of resveratrol $(5,708.05 \mu \mathrm{g} / \mathrm{g})$, and small amounts of gallic acid, coumaric acid and rutin were detected in $V$. arvensis. Compared to other flowers studied, the number of phenolic compounds in A. schoenoprasum was low, as ferulic acid, gallic acid, coumaric acid and rutin were detected. The lowest number of phenolic compounds from the edible flowers studied was in S. pratensis, where only gallic acid, catechin and cinnamic acid were identified, and these in small amounts. As mentioned for $R$. acetosa, previous works reported phenolic compounds in other plant parts (e.g. Miliauskas et al.) [35]. The lowest total concentration of phenolic compounds was in $T$. officinale and T. pratensis.

Phenolic compounds are now known to modulate human physiology and cell transduction pathways. They can also stimulate immune response, specifically to recognize and destroy cancer cells as well as to inhibit angiogenesis, which is necessary for tumor growth [36]. Furthermore, they can attenuate the adhesiveness and invasiveness of cancer cells, thereby reducing their metastatic potential. Human Hepatocellular Carcinoma (HepG2) and the Human Immortalized Nontumorogenic Keratinocyte (HaCaT) cell-lines are widely used to investigate proliferation activity associated with 


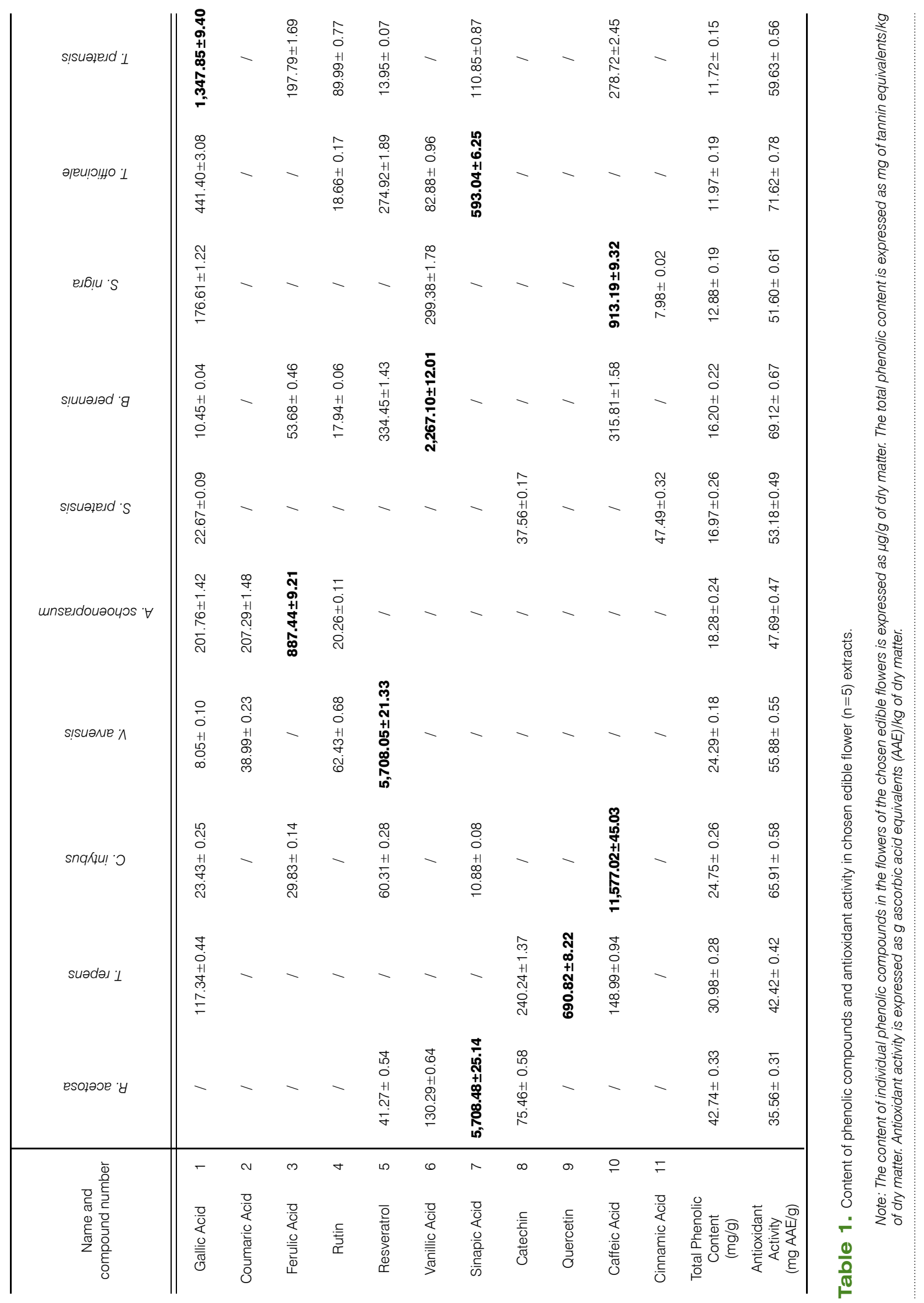


phenolic compounds [37-39]. In this study, treatment of the these cell lines with extracted phenolic compounds altered cell viability, but the pattern of dose dependency was different between the two cell lines (Table 2). More specifically, cell viability of $\mathrm{HaCaT}$ cell lines decreased as dosage increased; in HepG2 cells, no clear relationship between concentration of phenolic extract and cell viability was observed. We believe this is at least partially due to the different origins of the cell lines: $\mathrm{HaCaT}$ is immortalized non-tumorigenic cells, while HepG2 is derived from a Hepatocellular Carcinoma. Thus, it appears that phenolic compounds have different effects on normal and cancer cells - which can be demonstrated in the work of Lee et al. [23], or Nakajima et al. [40], who detected stronger cytotoxicity of phenolic compounds against normal rather than cancer cells. These differences may also provide explanation for the lesser effect of phenolic compounds on HepG2 viability, which was approximately $50 \%$ in HepG2 compared to $80 \%$ in $\mathrm{HaCaT}$ at $50 \mu \mathrm{g} / \mathrm{ml}$ for all extracts excluding that of $A$. schoenoprasum, where the effect was similarly high in both cell lines (with a decrease of about $80 \%$ ). This last result was not predicted, as $A$. schoenoprasum is in the bottom three species in this study for both concentration and number of phenolic compounds (see Table 1). Increasing cell viability, with decreasing phenolic compound concentration, was observed in the case of $\mathrm{HaCaT}$ on all representatives of Asteraceae, $R$. acetosa and $V$. arvensis. Nevertheless, a phenolic compound concentration of 75 and $100 \mu \mathrm{g} / \mathrm{ml}$ has a similar effect, because these two concentrations reach similar cell viabilities. The HepG2, as the more resistant cell-line, can give us more suitable results. On this cell-line, it can be demonstrated that different concentrations do not influence the results, as we expected. The statistical differences between the cell viability of individual concentration of phenolic compounds compared to the control are presented in Table 2. The differences were statistically significant (level of significance: $\mathrm{P} \leq 0.05$ ) in all cases - except for two. Overall, based on the results of HepG2, we deduce that $A$. schoenoprasum has the greatest impact on cell viability, and $R$. acetosa the least. The exact source of these effects, however, awaits further investigation.

The molecular targets of phenolic compounds are thought to be modulation of transduction pathways (i.e., mitogen-activated protein kinases, protein kinases $C$, phosphoinositide 3-kinase, glycogen synthase kinase) and regulation of gene expressions involved in cell proliferation, differentiation and apoptosis (e.g., c-myc expression). The findings of this study may provide particular insight into interactions with stress-activated NF-KB and AP-1 signal cascades, which are regarded as major therapeutic targets. In addition, estrogen receptors are thought to be sensitive to phenolic compounds [22]. Support for this possibility lies in the fact that both cell-lines used in the present study are estrogen receptor positive (HepG2 [41]; HaCaT [42]). For example, resveratrol [43], detected in a huge amount in $V$. arvensis flowers and in smaller amounts in $R$. acetosa, $C$. intybus, B. perennis, T. officinale and T. pratensis flowers has the ability to bind to both estrogen receptors and act as a mixed agonist/ antagonist. Consequently, resveratrol can have a potent effect, even in low-doses, through the aryl hydrocarbon receptor [44] that plays an important role in cancer cells [45]. Resveratrol not only influences estrogen receptors, but down-regulates the nuclear factor-KB [46], another important therapeutic target. The nuclear factor-KB may even be influenced by gallic acid [47] (present in great amounts in T. pratensis), quercetin [48], (which was detected in $T$. repens) or coumaric acid [49] (present only in $V$. arvensis and $A$. schoenoprasum). Gallic, caffeic, ferulic and sinapic acids alter another key signal cascade, AP-1 [50], and these acids were present in large amounts in $T$. pratensis, $C$. intybus, $A$. schoenoprasum and $R$. acetosa.

According to the results obtained for HepG2, we can deduce that $A$. schoenoprasum has the best impact on cell viability, and $R$. acetosa the worst. The other flowers tested have a similar effect. This is probably due to different phenolic compound compositions and undetected compounds present in the extracts.

The composition of edible flower phenolic compounds is presented here for the first time. We found that the effect of herbal extracts from flowers greatly altered viability of $\mathrm{HepG} 2$ and $\mathrm{HaCaT}$ cells. These effects were dependent on both concentration and profile of these compounds, but also appear to be cell-line dependent, and we believe the cell type (immortalized vs. cancerous) may be the cause. Clearly, the possibility of other compounds present but undetected may play a role in these responses, but this work provides significant insight upon which to generate further investigation.

\section{Acknowledgements}

This article was created with the support of the Operational Program Research and Development for Innovations, co-funded by the European Regional Development Fund (ERDF) and the national budget of the Czech Republic; within the framework of a Centre of Polymer Systems project (Reg. №: CZ.1.05/2.1.00/03.0111). Author Z. Kucekova also thanks support from the internal grant of TBU in Zlin No. IGA/FT/2013/019, funded from three sources of specific university research. 


\begin{tabular}{|c|c|c|c|c|c|}
\hline \multicolumn{2}{|c|}{ Concentration of phenolic compounds in medium. } & HepG2 & $\%$ & HaCaT & $\%$ \\
\hline \multirow{4}{*}{ R. acetosa } & 25 & $0.4971 \pm 0.0328$ * & 77.19 & $0.5873 \pm 0.0671$ * & 71.74 \\
\hline & 50 & $0.3769 \pm 0.0254$ * & 58.52 & $0.4472 \pm 0.0643$ * & 54.62 \\
\hline & 75 & $0.4268 \pm 0.0659$ * & 66.27 & $0.2367 \pm 0.0578$ * & 28.91 \\
\hline & 100 & $0.4829 \pm 0.0145$ * & 74.98 & $0.1903 \pm 0.0203$ * & 23.24 \\
\hline \multirow{4}{*}{ T. repens } & 25 & $0.3453 \pm 0.0513$ * & 53.62 & $0.3265 \pm 0.1159$ * & 39.88 \\
\hline & 50 & $0.2841 \pm 0.0330$ * & 44.11 & $0.1800 \pm 0.0201$ * & 21.99 \\
\hline & 75 & $0.2944 \pm 0.0226$ * & 45.71 & $0.1850 \pm 0.0071$ * & 22.6 \\
\hline & 100 & $0.3023 \pm 0.0173$ * & 46.94 & $0.1858 \pm 0.0114$ * & 22.69 \\
\hline \multirow{4}{*}{ V. arvensis } & 25 & $0.2918 \pm 0.0286$ * & 45.31 & $0.7983 \pm 0.2109 \mathrm{NS}$ & 97.51 \\
\hline & 50 & $0.2543 \pm 0.0556$ * & 39.49 & $0.4663 \pm 0.0789$ * & 56.96 \\
\hline & 75 & $0.2684 \pm 0.0158$ * & 41.68 & $0.1788 \pm 0.0097$ * & 21.84 \\
\hline & 100 & $0.3070 \pm 0.0172$ * & 47.67 & $0.1750 \pm 0.0157$ * & 21.38 \\
\hline \multirow{4}{*}{ A. schoenoprasum } & 25 & $0.1642 \pm 0.0139$ * & 25.5 & $0.1975 \pm 0.0128$ * & 24.12 \\
\hline & 50 & $0.1492 \pm 0.0030$ * & 23.17 & $0.2043 \pm 0.0253$ * & 24.95 \\
\hline & 75 & $0.1444 \pm 0.0129$ * & 22.42 & $0.2151 \pm 0.0164$ * & 26.27 \\
\hline & 100 & $0.1690 \pm 0.0034$ * & 26.24 & $0.1930 \pm 0.0221$ * & 23.57 \\
\hline \multirow{4}{*}{ S. pratensis } & 25 & $0.4250 \pm 0.0944$ * & 65.99 & $0.1678 \pm 0.0085$ * & 20.5 \\
\hline & 50 & $0.2712 \pm 0.0147$ * & 42.11 & $0.1667 \pm 0.0058$ * & 20.36 \\
\hline & 75 & $0.3594 \pm 0.0504$ * & 55.81 & $0.1725 \pm 0.0073$ * & 21.07 \\
\hline & 100 & $0.4105 \pm 0.0328$ * & 63.74 & $0.1775 \pm 0.0167$ * & 21.68 \\
\hline \multirow{3}{*}{ S. nigra } & 25 & $0.4786 \pm 0.0353$ * & 74.32 & $0.6403 \pm 0.0759 \mathrm{NS}$ & 78.21 \\
\hline & 50 & $0.4665 \pm 0.0496$ * & 72.44 & $0.1627 \pm 0.0080$ * & 19.87 \\
\hline & 75 & $0.2489 \pm 0.0336$ * & 38.65 & $0.1715 \pm 0.0099$ * & 20.95 \\
\hline \multirow{5}{*}{ C. intybus } & 100 & $0.3043 \pm 0.0205$ * & 47.25 & $0.1733 \pm 0.0091$ * & 21.17 \\
\hline & 25 & $0.4438 \pm 0.0385$ * & 68.91 & $0.6041 \pm 0.1002$ * & 73.79 \\
\hline & 50 & $0.4600 \pm 0.0424$ * & 71.43 & $0.1955 \pm 0.0520$ * & 23.88 \\
\hline & 75 & $0.2753 \pm 0.0125$ * & 42.75 & $0.1758 \pm 0.0083$ * & 21.47 \\
\hline & 100 & $0.3522 \pm 0.0331$ * & 54.69 & $0.1654 \pm 0.0116$ * & 20.20 \\
\hline \multirow{5}{*}{ Asteraceae } & 25 & $0.2248 \pm 0.0196$ * & 34.91 & $0.1933 \pm 0.0132$ * & 23.61 \\
\hline & 50 & $0.2928 \pm 0.0192$ * & 45.47 & $0.1719 \pm 0.0124$ * & 21.00 \\
\hline & 75 & $0.2938 \pm 0.0307$ * & 45.62 & $0.1763 \pm 0.0146$ * & 21.53 \\
\hline & 100 & $0.3606 \pm 0.0141$ * & 55.99 & $0.1772 \pm 0.0141$ * & 21.64 \\
\hline & 25 & $0.5110 \pm 0.0354$ * & 79.35 & $0.5346 \pm 0.0620$ * & 65.3 \\
\hline \multirow{3}{*}{ T. officinale } & 50 & $0.3788 \pm 0.0178$ * & 58.82 & $0.4260 \pm 0.1193$ * & 52.03 \\
\hline & 75 & $0.2817 \pm 0.0256$ * & 43.74 & $0.2901 \pm 0.1035$ * & 35.43 \\
\hline & 100 & $0.2337 \pm 0.0274$ * & 36.29 & $0.1880 \pm 0.0148$ * & 22.96 \\
\hline \multirow{4}{*}{ T. pratensis } & 25 & $0.3500 \pm 0.0468$ * & 54.35 & $0.4090 \pm 0.0216$ * & 49.96 \\
\hline & 50 & $0.3256 \pm 0.0310$ * & 50.56 & $0.1991 \pm 0.0433$ * & 24.32 \\
\hline & 75 & $0.3536 \pm 0.0273$ * & 54.91 & $0.1666 \pm 0.0104$ * & 20.35 \\
\hline & 100 & $0.3582 \pm 0.0331$ * & 55.62 & $0.1738 \pm 0.0165$ * & 21.23 \\
\hline Control & & $0.6440 \pm 0.0498 * *$ & 100 & $0.8187 \pm 0.1806 * \star$ & 100 \\
\hline
\end{tabular}

Table 2. Proliferation of HaCaT and HepG2 in the presence of different concentration of phenolic compounds in a medium ( $\mu \mathrm{g} / \mathrm{ml})$ quantified by MTT Assay (Average Absorbance \pm SD)

Note: \% represents decreasing absorbance in percentage as compared to the control. Values with different superscripts show significance level within column: $P<0.05 \quad\left(^{*},{ }^{* *}\right)$, NS: non-significant difference 
[1] Mlcek J., Rop O., Fresh edible flowers of ornamental plants - A new source of nutraceutical foods, Trends Food Sci. Tech., 2011, 22, 561-569

[2] Sharif T., Auger C., Alhosin M., Ebel C., Achour M., Étienne-Selloum N., et al., Red wine phenolic compounds cause growth inhibition and apoptosis in acute lymphoblastic leukaemia cells by inducing a redoxsensitive up-regulation of $\mathrm{p} 73$ and downregulation of UHRF1, Eur. J. Cancer, 2010, 46, 983-994

[3] Castillo-Pichardo L., Martínez-Montemayor M.M., Martínez J.E., Wall K.M., Cubano L.A., Dharmawardhane S., Inhibition of mammary tumor growth and metastases to bone and liver by dietary grape phenolic compounds, Clin. Exp. Metastasis., 2009, 26, 505-516

[4] Damianaki A., Bakogeorgou E., Kampa M., Notas G., Hatzoglou A., Panagiotou S., Gemetzi C., et al., Potent inhibitory action of red wine phenolic compounds on human breast cancer cells, J. Cell. Biochem., 2000, 78, 429-441

[5] Yilmaz Y., Toledo R.T., Major flavonoids in grape seeds and skins: Antioxidant capacity of catechin, epicatechin, and gallic acid, J. Agr. Food Chem., 2004, 52, 255-260

[6] Jin H., Tan X., Liu X., Ding Y., The study of effect of tea phenolic compounds on microsatellite instability colorectal cancer and its molecular mechanism, Int. J.Colorectal Dis., 2010, 25, 1407-1415

[7] Oak M.H., El Bedoui J., Schini-Kerth V.B., Antiangiogenic properties of natural phenolic compounds from red wine and green tea, J. Nutr. Biochem., 2005, 16, 1-8

[8] Luceri C., Caderni G., Sanna A., Piero D., Red wine and black tea phenolic compounds modulate the expression of cycloxygenase-2, inducible nitric oxide synthase and glutathione-related enzymes in azoxymethane-induced F344 rat colon tumors, J. Nutr., 2002, 132, 1376-1379

[9] Kuroda Y., Hara Y., Antimutagenic and anticarcinogenic activity of tea phenolic compounds, Mutat. Res., 1999, 436, 69-97

[10] Schlachterman A., Valle F., Wall K.M., Azios N.G., Castillo L., Morell L., et al., Combined resveratrol, quercetin, and catechin treatment reduces breast tumor growth in a nude mouse model, Transl. Oncol., 2008, 1, 19-27

[11] Lin J.K., Liang Y.C., Lin-Shiau S.Y., Cancer chemoprevention by tea phenolic compounds through mitotic signal transduction blockade, Biochem. Pharmacol., 1999, 58, 911-915
[12] Soleas G.J., Grass L., Josephy P.D., Goldberg D.M., Diamandis E.P., A comparison of the anticarcinogenic properties of four red wine phenolic compounds, Clin. Biochem., 2002, 35, 119-124

[13] Nichenametla S.N., Taruscio T.G., Barney D.L., Exon J.H., A review of the effects and mechanisms of polyphenolics in cancer, Crit. Rev. Food Sci. Nutr., 2006, 46, 161-183

[14] Link A., Balaguer F., Goel A., Cancer chemoprevention by dietary phenolic compounds: Promising role for epigenetics, Biochem. Pharmacol., 2010, 80, 1771-1792

[15] Navarro-Perán E., Cabezas-Herrera J., Campo L.S., Rodríguez-López J.N., Effects of folate cycle disruption by the green tea polyphenol epigallocatechin-3-gallate, Int. J. Biochem. Cell Biol., 2007, 39, 2215-2225

[16] Poon V.K.M, Burd A., In vitro cytotoxity of silver: implication for clinical wound care, Burns, 2004, 30, 140-147

[17] Herzog E., Casey A., Lyng F.M., Chambers G., Byrne H.J., Davoren M., A new approach to the toxicity testing of carbon-based nanomaterials-the clonogenic assay, Toxicol Lett. 2007, 174, 49-60

[18] Mascotti K., McCullough J., Burger S.R., HPC viability measurement: trypan blue versus acridine orange and propidium iodide, Transfusion, 2002, 40, 693-696

[19] Strober W., Trypan blue exclusion test of cell viability, Curr Protoc Immunol., 2001, 21, A.3B.1A.3B. 2

[20] Moravcikova D., Kucekova Z., Mlcek J., Rop O., Humpolicek P., Compositions of polyphenols in wild chive, meadow salsify, garden sorrel and ag yoncha and their anti-proliferative effect, Acta Univ. Agric. Et Silvic. Mendel. Brun., 2012, 60, 125-132

[21] Mosmann T., Rapid colorimetric assay for cellular growth and survival: application to proliferation and cytotoxicity assays, J. Immunol. Methods, 1983, $65,55-63$

[22] Hakimuddin F., Tiwari K., Paliyath G., Meckling K., Grape and wine phenolic compounds downregulate the expression of signal transduction genes and inhibit the growth of estrogen receptornegative MDA-MB231 tumors in nu/nu mouse xenografts, Nutr. Res., 2008, 28, 702-713

[23] Lee Y.T., Don M.J., Hung P.S., Shen Y.C., Lo Y.S., Chang K.W., et al., Cytotoxicity of phenolic acid phenethyl esters on oral cancer cells, Cancer Lett. Vol., 2004, 223, 19-25 
[24] Brand-Williams W., Cuvelier M.E., Berset C., Use of a free radical method to evaluate antioxidant aktivity, LWT-Food Sci. Technol., 1995, 28, 25-30

[25] Thaipong K., Boonprakob U., Crosby K., CisnerosZevallos L., Byrne D.H., Comparison of ABTS, DPPH, FRAP, and ORAC assays for estimating antioxidant activity from guava fruit extracts, J. Food Compos. Anal., 2006, 19, 669-675

[26] Rupasinghe H.P.V., Jayasankar S., Lay W., Variation in total phenolic and antioxidant capacity among European plum genotypes, Sci. Hortic., 2006, 108, 243-246

[27] Boukamp P., Petrussevska R., Breitkreutz D., Hornung J., Markham A., Normal keratinization in a spontaneously immortalized aneuploid keratinocyte cell line, J. Cell. Biol., 1988, 106, 761771

[28] Kucekova Z., Mlcek J., Humpolicek P., Rop O., Valasek P., Saha P., Phenolic compounds contained in Allium schoenoprasum, Tragopogon pratensis and Rumex acetosa and thein antiproliferative effect, Molecules, 2011, 16, 9207-17

[29] Brighente I.M.C., Dias M., Verdi L.G., Pizzolatti M.G., Antioxidant Activity and Total Phenolic Content of Some Brazilian Species, Pharm. Biol., 2007, 45, 156-161

[30] Spina M., Cuccioloni M., Sparapani L., Acciarri S., Eleuteri A., Fioretti E., et al., Comparative evaluation of flavonoid content in assessing quality of wild and cultivated vegetables for human consumption, J. Sci. Food Agr., 2008, 88, 294-304

[31] Rieger G., Muller M., Guttenberger H., Bucar F., Influence of altitudinal variation on the content of phenolic compounds in wild populations of Calluna vulgaris, Sambucus nigra, and Vaccinium myrtillus, J. Agr. Food Chem., 2008, 56, 9080-9086

[32] Tolra R.P, Poschenrieder C., Luppi B., Barce, J., Aluminium-induced changes in the profiles of both organic acids and phenolic substances underlie Al tolerance in Rumex acetosa L., Environ. Exp. Bot., 2005, 54, 231-238

[33] Stoggl W.M., Huck C.W., Bonn G.K., Structural elucidation of catechin and epicatechin in sorrel leaf extracts using liquid-chromatography coupled to diode array-, fluorescence-, and mass spectrometric detection, J. Sep. Sci., 2004, 27, 524-528

[34] Severino J.F., Stich K., Soja G., Ozone stress and antioxidant substances in Trifolium repens and Centaurea jacea leaves, Environ. Pollut., 2007, 146, 707-714

[35] Miliauskas G., Venskutonis P.R., van Beek T.A., Screening of radical scavenging activity of some medicinal and aromatic plant extracts, Food Chem., 2004, 85, 231-237

[36] Newell A., Yousef G., Lila M.A., Ramírez-Mares M.V., Gonzalez de Mejia E., Comparative in vitro bioactivities of tea extracts from six species of Ardisia and thein effect on growth inhibition of HepG2 cells, J. Ethnopharmacol., 2010, 130, 536544

[37] Yu H.B., Li D.Y., Zhang H.F., Xue H.Z., Pan C.E., Zhao S.H., et al., Resveratrol Inhibits Invasion and Metastasis of Hepatocellular Carcinoma Cells, J. Anim. Vet. Adv., 2010, 9, 3117-3124

[38] Belen G.A., Angeles M.M., Bravo L., Goya L., Ramos S., Quercetin modulates NF-KB and AP-1/JNK pathways to induce cell death in human hepatoma cells, Nutr. Cancer, 2010, 62, 390-401

[39] Svobodova A., Zdarilova A., Vostalova J., Lonicera caerulea and Vaccinium myrtillus fruit phenolic compounds protect $\mathrm{HaCaT}$ keratinocytes against UVB-induced phototoxic stress and DNA damage, J. Dermatol. Sci., 2009, 56, 196-204

[40] Nakajima Y., Nishida H., Matsugo S., Konishi T., Cancer cell cytotoxicity of extracts and small phenolic compounds from Chaga, J. Med. Food, 2009, 12, 501-507

[41] Solakidi S., Psarra A.M.G., Sekeris C.E., Differential subcellular distribution of estrogen receptor isoforms: Localization of ER alpha in the nucleoli and ER beta in the mitochondria of human osteosarcoma SaOS-2 and hepatocarcinoma HepG2 cell lines, BBA-Mol. Cel. Res., 2005, 1745, 382-392

[42] Planas-Silva M.D., Donaher J.L., Weinberg R.A.M., Functional activity of ectopically expressed estrogen receptor is not sufficient for estrogenmediated cyclin D1 expression, Cancer Res., 1999, 59, 4788-4792

[43] Bowers J.L., Tyulmenkov V.V., Jernigan S.C., Klinge C.M., Resveratrol acts as a mixed agonist/ antagonist for estrogen receptors alpha and beta, Endocrinology, 2000, 141, 3657-3667

[44] Perdew G.H., Hollingshead B.D., DiNatale B.C., Morales J.L., Labrecque M.P., Takhar M.K., et al., Estrogen receptor expression is required for low-dose Resveratrol-mediated repression of aryl hydrocarbon receptor activity source, J. Pharmacol. Exp. Ther., 2010, 335, 273-283

[45] Barhoover M.A., Hall J.M., Greenlee W.F., Thomas R.S., Aryl hydrocarbon receptor regulates cell cycle progression in human breast cancer cells via a functional interaction with cyclin-dependent kinase 4, Mol. Pharmacol., 2010, 77, 195-201 
[46] Narayanan B.A., Narayanan N.K., Re G.G., Nixon D.W., Differential expression of genes induced by resveratrol in LNCaP cells: P53-mediated molecular targets, Int. J. Cancer, 2003, 104, 204212

[47] Kao T.K., Ou Y.C., Raung S.L., Chen W.Y., Yen Y.J., Lai C.Y., et al., Graptopetalum paraguayense E. Walther leaf extracts protect against brain injury in ischemic rats, Am. J. Chinese Med., 2010, 38, 495-516

[48] Kim B.H., Lee I.J., Lee H.Y., Han S.B., Hong J.T., Ahn B., et al., Quercetin 3-O-beta-(2“- galloyl)-glucopyranoside inhibits endotoxin LPSinduced IL-6 expression and NF-KB activation in macrophages, Cytokine, 2007, 39, 207-215

[49] Szliszka E., Zydowicz G., Janoszka B., Dobosz C., Kowalczyk-Ziomek G., Krol W., Ethanolic extract of Brazilian green propolis sensitizes prostate cancer cells to TRAIL-induced apoptosis, Int. J. Oncol., 2011, 38, 941-953

[50] Maggi-Capeyron M.F., Ceballos P., Cristol J.P., Delbosc S., Le Doucen C., Pons M., et al., Wine phenolic antioxidants inhibit AP-1 transcriptional activity, J. Agr. Food Chem., 2001, 49, 5646-5652 